\title{
INDIKATOR KESETARAAN GENDER DAN ISU-ISU GENDER DI BIDANG PENDIDIKAN
}

\author{
Maidin Gultom \\ Fakultas Hukum Universitas Katolik Santo Thomas, Medan, Indonesia \\ Email : gultommaidin@gmail.com
}

\begin{abstract}
ABSTRAK
Gender adalah konstruksi sosial maupun kultural yang dilekatkan oleh masyarakat pada laki-laki dan perempuan. Misalnya perempuan lemah lembut, penyayang, sabar dan tekun. Sedangkan laki-laki tegas, berwibawa, tidak cengeng dan sebagainya. Pembedaan gender ini kemudian diperkuat pula dengan mitos dan pembagian kerja seksual yang berlaku bagi masing-masing jenis kelamin. Misalnya perempuan lebih sesuai untuk memilih jurusan sastra, sosial atau ekonomi sedangkan laki-laki lebih cocok masuk jurusan teknik. Perempuan lebih cocok menjadi sekretaris, laki-laki lebih cocok bekerja di lapangan (hutan, lepas pantai, dan lain-lain). Bila sebuah keluarga memiliki dana terbatas untuk menyekolahkan anak-anaknya, prioritas akan diberikan kepada anak laki-laki untuk melanjutkan sekolah. Anak perempuan diharapkan dapat menerima ini karena "setinggi-tingginya perempuan sekolah, nantinya akan ke dapur juga." Perbedaan-perbedaan gender dikarenakan banyak hal, di antaranya dibentuk, disosialisasikan, diperkuat, bahkan dikonstruksi secara sosio kultural, melalui ajaran keagamaan maupun negara. Meniadakan diskriminasi tersebut di atas, kita membutuhkan kesetaraan gender (gender equality) atau pandangan bahwa perempuan dan laki-laki memiliki akses dan kesempatan yang sama di segala bidang. Kesetaraan gender bukan berarti perempuan harus menjadi sama dengan laki-laki, karena secara kodrati perempuan memang berbeda dengan laki-laki. Kesetaraan gender lebih berarti negara melakukan tindakan untuk memberikan kesempatan dan hak yang sama bagi laki-laki dan perempuan.
\end{abstract}

\section{Kata Kunci : Kesetaraan, Gender, Pendidikan}

\begin{abstract}
Gender is a social and cultural construction that is attached by society to men and women. For example, women are gentle, compassionate, patient and diligent. While men are firm, dignified, not weepy and so on. This gender distinction is further strengthened by the myths and sexual division of labor that apply to each sex. For example, women are more suitable to choose literature, social or economic majors, while men are more suitable to enter engineering majors. Women are more suitable to be secretaries, men are more suitable to work in the field (forest, offshore, etc.). If a family has limited funds to send their children to school, priority will be given to boys to continue their studies. Girls are expected to accept this because "as high as school girls, they will go to the kitchen too." Gender differences are due to many things, including being formed, socialized, strengthened, even constructed socio-cultural, through religious and state teachings. Eliminating the discrimination mentioned above, we need gender equality or the view that women and men have equal access and opportunities in all fields. Gender equality does not mean that women have to be the same as men, because women are naturally different from men. Gender equality means that the state takes action to provide equal opportunities and rights for men and women.
\end{abstract}

Keywords: Equality, Gender, Education 


\section{A. PENDAhULUAN \\ 1. Pengertian Gender}

Gender berbeda dengan jenis kelamin.Gender adalah perbedaan antara laki-laki dan perempuan dalam peran, fungsi, hak, tanggung jawab, dan perilaku yang dibentuk oleh tata nilai sosial, budaya dan adat istiadat. Ciri-cirinya adalah:

Ciri-ciri fisik

\begin{tabular}{|c|c|c|}
\hline & Laki-laki & Perempuan \\
\hline $\begin{array}{l}\text { Ciri-ciri Fisik } \\
\text { Utama }\end{array}$ & $\begin{array}{ll}\sigma & \text { Penis } \\
\sigma & \text { Zakar (buah pelir) } \\
& \text { Sperma / mani }\end{array}$ & $\begin{array}{l}\text { Vagina (Lubang } \\
\text { senggama) } \\
\sigma \quad \text { Sel telur } \\
\text { Payudara }\end{array}$ \\
\hline Ciri-ciri fisik tambahan & $\begin{array}{l}\text { Jakun, Kumis dan Janggut } \\
\text { Dada bidang }\end{array}$ & $\begin{array}{ll} & \text { Kulit Halus } \\
& \text { Pinggul besar }\end{array}$ \\
\hline
\end{tabular}

\section{Perbedaan Gender dengan Jenis Kelamin}

Jenis Kelamin (seks) adalah perbedaan fisik biologis, yang mudah dilihat melalui ciri fisik primer dan secara sekunder yang ada pada kaum laki-laki dan perempuan. Perbedaannya adalah:

\section{Perbedaan antara Gender dengan Jenis Kelamin}

\begin{tabular}{|l|l|l|l|}
\hline \multicolumn{1}{|c|}{ Jenis Kelamin } & \multicolumn{1}{|c|}{ Contoh } & \multicolumn{1}{c|}{ Gender } & \multicolumn{1}{c|}{ Contoh } \\
\hline \hline Tidak dapat berubah & $\begin{array}{l}\text { Alat kelamin laki-laki dan } \\
\text { perempuan }\end{array}$ & Dapat berubah & \\
\hline \hline $\begin{array}{l}\text { Tidak dapat } \\
\text { dipertukarkan }\end{array}$ & $\begin{array}{l}\text { Jakun pada laki-laki dan } \\
\text { payudara pada perempuan }\end{array}$ & $\begin{array}{l}\text { Dapat } \\
\text { dipertukarkan }\end{array}$ & \\
\hline $\begin{array}{l}\text { Berlaku sepanjang } \\
\text { masa }\end{array}$ & $\begin{array}{l}\text { Status sebagai laki-laki } \\
\text { atau perempuan }\end{array}$ & $\begin{array}{l}\text { Tergantung budaya } \\
\text { dan kebiasaan }\end{array}$ & \\
\hline Berlaku dimana saja & $\begin{array}{l}\text { Dirumah, dikantor dan } \\
\text { dimanapun berada, } \\
\text { seorang lelaki atau } \\
\text { perempuan tetap laki-laki } \\
\text { dan perempuan }\end{array}$ & $\begin{array}{l}\text { Peran laki-laki / } \\
\text { perempuan } \\
\text { tergantung budaya } \\
\text { setempat }\end{array}$ & $\begin{array}{l}\text { Pembatasan } \\
\text { kesempatan } \\
\text { dibidang } \\
\text { pekerjaan. }\end{array}$ \\
\hline $\begin{array}{l}\text { Merupakan Kodrat } \\
\text { Tuhan YME }\end{array}$ & $\begin{array}{l}\text { Laki-laki mempunyai ciri- } \\
\text { ciri utama yang berbeda } \\
\text { dengan ciri utama } \\
\text { perempuan }\end{array}$ & $\begin{array}{l}\text { Bukan merupakan } \\
\text { Kodrat Tuhan }\end{array}$ & $\begin{array}{l}\text { Perencanaan } \\
\text { jumlah anak } \\
\text { dalam suatu } \\
\text { keluarga }\end{array}$ \\
\hline \hline Ciptaan Tuhan & $\begin{array}{l}\text { Perempuan bisa haid, } \\
\text { hamil, melahirkan dan } \\
\text { menyusui, sedangkan laki- } \\
\text { laki tidak }\end{array}$ & Buatan Manusia & $\begin{array}{l}\text { Laki-laki dan } \\
\text { perempuan berhak } \\
\text { menjadi Calon } \\
\text { Ketua RT, RW, } \\
\text { Kades bahkan } \\
\text { Presiden }\end{array}$ \\
\hline
\end{tabular}

\section{stilah-istilah Gender}

Istilah-istilah yang perlu

dipahami dalam hyal ini adalah:

\section{Pengarusutamaan Gender}

Adalah suatu strategi untuk mencapai kesetaraan dan keadilan gender. Strategi ini dilakukan melalui kebijakan dan program yang memperhatikan pengalaman, aspirasi, kebutuhan dan permasalahan perempuan dan laki-laki. Kebijakan dan program tersebut mencakup seluruh 
aspek kehidupan dan pembangunan serta meliputi tahap perencanaan, pelaksanaan, pemantauan dan evaluasi.

\section{Kesenjangan Gender}

Adalah ketidak seimbangan peran dan kedudukan antara perempuan dan laki-laki dalam proses pembangunan.

\section{Patriarkhi}

Tata nilai sosial budaya suatu masyarakat yang menempatkan ayah (laki-laki) sebagai pemimpin keluarga.

\section{Buta Gender}

Adalah anggapan bahwa pilihan pekerjaan bagi perempuan dan laki-laki sudah ditentukan sesuai kodrat.

\section{Diskriminasi Gender}

Adalah memperlakukan seseorang atau kelompok orang secara berbeda karena jenis kelamin.

\section{Kesadaran Gender}

Adalah pengetahuan dan pemahaman seseorang akan kesamaan peran \& tanggung jawab laki-laki \& perempuan dalam kehidupan bekeluarga dan bermasyarakat.

\section{Bias Gender}

Adalah suatu pandangan dan sikap yang lebih mengutamakan salah satu jenis kelamin dibanding jenis kelamin lain.

Bentuk-bentuk ketidakadilan dalam gender adalah:

\section{Subordinasi atau menomor duakan Perempuan}

Contoh :

a. Perempuan adalah orang belakang (koncowingking)

b. Perempuan dinomorduakan dalam politik, jabatan, karir dan pendidikan

\section{Pelabelan negatif (Citra baku)}

Contoh :

a. Perempuan memasak, bersolek dan melahirkan

b. Janda mudah dirayu

c. Perempuan mudah dibeli dengan uang d. Laki-laki penggoda dan berkuasa

\section{Kekerasan}

Contoh :

a. Penyiksaan dan pemukulan terhadap istri

b. Kata dan permintaan suami harus dipatuhi

c. Perkosaan, pelecehan seksual

\section{Beban Ganda}

Contoh :

a. Perempuan bekerja di dalam rumah dan diluar rumah

b. Laki-laki mencari nafkah di luar rumah

c. Istri harus bekerja mengurus anak, menyediakan hidangan, dan mengurus rumah tangga

\section{Marginalisasi (peminggiran)}

Contoh :

a. Upah perempuan lebih kecil dari laki-laki untuk pekerjaan yang sama

b. Jika perempuan lajang mau berusaha/bekerja harus seizin ayahnya

c. Permohonan kredit harus dengan persetujuan suami, tidak sebaliknya.

Berdasarkan latar belakang

masalah di atas, yang menjadi permasalahan adalah:

1. Apakah manfaat kesetaraan gender dan keadilan gender?

2. Bagaimana pemberdayaan perempuan dalam rangka kesetaraan gender?

B. PEMBAHASAN

1. Manfaat Kesetaraan Gender dan Keadilan Gender

Kesetaraan Gender adalah kesamaan peluang dan kesempatan dalam bidang sosial, politik dan ekonomi antara laki-laki dan Perempuan. Keadilan Gender adalah suatu perlakuan yang sesuai dengan hak dan kewajinan sebagai manusia yang 
bermartabat dalam keluarga dan masyarakat.

Perempuan dan laki-laki adalah makhluk yang memiliki potensi sama. Kerjasama mereka dapat mempercepat kemajuan pembangunan di segala bidang. Contoh: pembangunan jembatan di desa akan cepat terlaksana apabila melibatkan perempuan dalam perancanaan, karena jumlah penduduk perempuan lebih banyak dan memberikan kesempatan kepada perempuan untuk berpartisipasi. Pembangunan sebaiknya memenuhi aspirasi dan kebutuhan laki-laki dan perempuan, misalnya: menyediakan fasilitas kesehatan \& tempat penitipan anak.

Sebagian besar masyarakat Indonesia tidak menyadari bahwa nilai budaya dan nilai sosial yang berlaku di Indonesia saat ini, telah memarjinalkan peranan perempuan di Indonesia dan secara khusus dalam konteks HAM telah mendiskriminasikan perempuan di Indonesia. Permasalahan gender di Indonesia adalah permasalahan yang kompleks, karena merupakan permasalahan yang dapat dilihat dari berbagai segi. Masalah gender di Indonesia, banyak dibenturkan dengan masalah budaya dan agama, dengan menekankan pada banyaknya perbedaan sudut pandang.

Gender adalah konstruksi sosial maupun kultural yang dilekatkan oleh masyarakat pada laki-laki dan perempuan. Misalnya perempuan lemah lembut, penyayang, sabar dan tekun. Sedangkan laki-laki tegas, berwibawa, tidak cengeng dan sebagainya. Pembedaan gender ini kemudian diperkuat pula dengan mitos dan pembagian kerja seksual yang berlaku bagi masing-masing jenis kelamin. Misalnya perempuan lebih sesuai untuk memilih jurusan sastra, sosial atau ekonomi sedangkan laki-laki lebih cocok masuk jurusan teknik. Perempuan lebih cocok menjadi sekretaris, laki-laki lebih cocok bekerja di lapangan (hutan, lepas pantai, dan lain-lain). Jadi ternyata gender bukanlah semata-mata pembedaan laki-laki dan perempuan berdasarkan jenis kelamin saja. Perbedaan-perbedaan gender dikarenakan banyak hal, di antaranya dibentuk, disosislisasikan, diperkuat, bahkan dikonstruksi secara sosio kultural, melalui ajaran keagamaan maupun negara. Seperti halnya pada pemerintahan orde baru dikenal organisasi yang khusus untuk perempuan, seperti PKK. Kegiatan PKK adalah menyangkut peranan kaum ibu/ibu rumah tangga; bukan membicarakan masalah-masalah politik, pemerintahan atau masalah-masalah dunia.

Dalam praktiknya hingga saat ini, pembagian gender itu telah menyebabkan ketidakadilan bagi perempuan. Misalnya bila sebuah keluarga memiliki dana terbatas untuk menyekolahkan anak-anaknya, perioritas akan diberikan kepada anak laki-laki untuk melanjutkan sekolah. Anak perempuan diharapkan dapat menerima ini karena "toh setinggitingginya perempuan sekolah, nantinya akan ke dapur juga".

Untuk meniadakan diskriminasi tersebut di atas, dibutuhkan kesetaraan gender (gender equality) atau pandangan bahwa perempuan dan lakilaki memiliki akses dan kesempatan yang sama di segala bidang. Kesetaraan gender bukan berarti perempuan harus menjadi sama dengan laki-laki, karena secara kodrati perempuan memang berbeda dengan laki-laki. Kesetaraan gender lebih berarti negara melakukan tindakan untuk memberikan kesempatan dan hak yang sama bagi laki-laki dan perempuan. Gender juga memiliki peran pada permasalahan-permasalahan yang 
muncul, sehubungan dengan perempuan sebagai korban kekerasan (baik dalam rumah tangga atau pada masyarakat). Perempuan dalam rumah tangga yang tidak berdaya secara ekonomi (karena tidak memiliki bekal pengetahuan yang cukup misalnya) cenderung lebih pasrah dan "nrimo" dengan keadaannya. Hal ini sering memicu atau meningkatkan adanya kekerasan. Lebih parah lagi, karena kekerasan ini dilakukan dalam ikatan perkawinan, maka perempuan tidak berkeinginan untuk melaporkannya kepada pihak yang berwajib. Permasalahan yang lebih kompleks timbul karena kekerasan yang muncul dalam rumah tangga dapat mempengaruhi jiwa anak-anak yang dibesarkan di dalamnya. Berkaitan dengan kekerasan dalam keluarga, telah diundangkan UU No. 23 Tahun 2004 tentang Penghapusan Kekerasan Dalam Rumah Tangga. Ada beberapa alasan kekerasan dalam rumah tangga diantisipasi, seperti: kekerasan terhadap perempuan tidak hanya karena berpengaruh terhadap derajat kesehatan fisik, keselamatan jiwa, dan berdampak psikologis yang negatif pada korban, tetapi juga karena dilecehkannya hakhak asasinya sebagai manusia. Namun ketidaksetaraan gender dan ketidakpastian hukum membuat banyak perempuan korban kekerasan, memilih tidak menyelesaikan kekerasan yang dialaminya secara hukum.

Kepekaan terhadap Kesetaraan dan Keadilan Gender akan bermanfaat bagi:

1. Diri sendiri

a. Menumbuhkan kesadaran akan kemampuan hak-hak yang sama antara laki-laki dan perempuan

b. Menumbuhkan keyakinan dan keberanian untuk memperjuangkan keadilan c. Menumbuhkan kemandirian dan kebebasan untuk menentukan pilihan sendiri

2. Keluarga

a. Menumbuhkan kesadaran dan perilaku kebersamaan untuk saling menghargai hak dan kewajiban antar individu dalam keluarga.

b. Menumbuhkan kesadaran akan pentingnya saling menghargai peran setiap individu.

3. Masyarakat

a. Menumbuhkan kesadaran bahwa pembangunan dapat tercapai bila dilaksanakan secara bersamasama dalam merencanakan, melaksanakan, memanfaatkan, menikmati dan memeliharanya secara berkelanjutan.

b. Menumbuhkan kesadaran akan pentingnya sikap saling menghargai dan menghormati hak-hak perorangan atau kelompok.

4. Negara

a. Mempermudah penyusunan dalam menetapkan kebijakan nasional

b. Mempermudah proses terjadinya pembangunan dari, oleh dan untuk rakyat.

\section{Pemberdayaan Perempuan Dalam} Rangka Kesetaraan Gender

Sebagian besar masyarakat Indonesia tidak menyadari bahwa nilai budaya dan nilai sosial yang berlaku di Indonesia saat ini telah memarjinalisasikan peranan perempuan di Indonesia dan secara khusus dalam konteks HAM telah mendiskriminasikan perempuan di Indonesia. Permasalahan gender di Indonesia adalah permasalahan yang kompleks karena merupakan permasalahan yang dapat dilihat secara multi faset. Masalah gender di Indonesia, banyak dibenturkan dengan 
masalah budaya dan agama dengan menekankan pada banyaknya perbedaan sudut pandang.

Gender adalah konstruksi sosial maupun kultural yang dilekatkan oleh masyarakat pada laki-laki dan perempuan. Misalnya perempuan lemah lembut, penyayang, sabar dan tekun. Sedangkan laki-laki tegas, berwibawa, tidak cengeng dan sebagainya. Pembedaan gender ini kemudian diperkuat pula dengan mitos dan pembagian kerja seksual yang berlaku bagi masing-masing jenis kelamin. Misalnya perempuan lebih sesuai untuk memilih jurusan sastra, sosial atau ekonomi sedangkan laki-laki lebih cocok masuk jurusan teknik. Perempuan lebih cocok menjadi sekretaris, laki-laki lebih cocok bekerja di lapangan (hutan, lepas pantai, dan lain-lain). Jadi ternyata gender bukanlah semata-mata pembedaan laki-laki dan perempuan berdasarkan jenis kelamin saja. Perbedaan-perbedaan gender dikarenakan banyak hal, di antaranya dibentuk, disosislisasikan, diperkuat, bahkan dikonstruksi secara sosio kultural, melalui ajaran keagamaan maupun negara. Seperti halnya pada pemerintahan orde baru dikenal organisasi yang khusus untuk perempuan, seperti PKK. Kegiatan PKK adalah menyangkut peranan kaum ibu/ibu rumah tangga; bukan membicarakan masalah-masalah politik, pemerintahan atau masalah-masalah dunia.

$$
\text { Melalui proses panjang, }
$$
sosialisasi gender tersebut akhirnya dianggap sebagai ketentuan Tuhan, seolah-olah bersifat biologis yang tidak bisa diubah lagi, sehingga perbedaanperbedaan gender dianggap dan dipahami sebagai kodrat laki-laki dan kodrat perempuan. Dengan demikian masyarakat di suatu tempat tertentu dan dalam kurun waktu tertentulah yang menentukan peran dan tanggungjawab seseorang yang berjenis kelamin lakilaki atau perempuan. Bila peranan yang telah dibakukan oleh masyarakat ini dilanggar, maka sanksi sosial dari masyarakat akan didapat oleh si pelanggarnya. Misalnya bila seorang wanita menjadi supir angkot (angkutan kota), akan mendapatkan cap "perempuan aneh atau perempuan yang kelaki-lakian" atau sebaliknya, laki-laki yang bekerja di rumah menjaga anakanaknya, akan dianggap "suami takut istri/di bawah ketiak istri (DKI)" dan lain sebagainya

Pada tahun 1981, Konvensi Penghapusan segala bentuk Diskriminasi terhadap wanita (Convention on the Elimination of Discrimination Against Women disingkat dengan CEDAW), mengakui: perbedaan biologis atau kodrati antara perempuan dan laki-laki; perbedaan perlakuan terhadap perempuan yang berbasis gender yang mengakibatkan kerugian pada perempuan; perbedaan kondisi dan posisi antara perempuan dan laki-laki dikarenakan adanya diskriminasi terhadap perempuan. Dalam konvensi ini dimuat beberapa kewajiban negara yang harus dilaksanakan untuk tujuan kesetaraan gender, antara lain kewajiban negara untuk: secara umum mengeliminasi diskriminasi terhadap perempuan; memberdayakan perempuan; melakukan percepatan tercapainya kesetaraan gender; melakukan revisi dan penyusunan peraturan perundangundangan yang mendudukkan perempuan secara setara di depan hukum, dalam ketenagakerjaan, dalam haknya sebagai warga negara dan sebagainya. Indonesia telah meratifikasi konvensi ini melalui UU No. 7 Tahun 1984 tentang Pengesahan mengenai Konvensi Penghapusan Segala Bentuk Kekerasan Terhadap Wanita. 
Salah satu kewajiban negara yang harus dipenuhi adalah pemberdayaan perempuan, dengan kegiatan-kegiatan: mempromosikan partisipasi perempuan sebagai agen pembaharu dalam proses politik, ekonomi dan sosial; kemitraan antara perempuan dan laki-laki, dalam arti terjadinya perubahan sikap, perilaku dan pengisian peran laki-laki dan perempuan di berbagai bidang; usahausaha khusus yang dapat menghapus ketimpangan gender di berbagai tingkatan.

\section{PENUTUP}

Hukum pada dasarnya merupakan pencerminan dari HAM, sehingga hukum itu mengandung keadilan atau tidak, ditentukan oleh HAM yang dikandung dan diatur atau dijamin oleh hukum itu. Hukum tidak lagi dilihat sebagai refleksi kekuasaan ssssematamata, tetapi juga harus memancarkan perlindungan terhadap hak-hak warga negara. Hukum yang berlandaskan nilai-nilai kemanusiaan mencerminkan norma-norma yang menghormati martabat manusia dan mengakui HAM. Norma-norma yang mengandung nilainilai luhur yang menjunjung tinggi martabat manusia dan menjamin HAM. HAM merupakan alat untuk memungkinkan warga masyarakat dengan bebas mengembangkan bakatnya untuk penunaian tugasnya dengan baik. Kemungkinan ini diselenggarakan oleh negara dengan jalan membentuk kaidah-kaidah atau peraturan-peraturan hukum, yang merupakan tugas penting negara. Kebebasan dijamin oleh negara demi kepentingan masyarakat. Kaidah hukum yang memungkinan anggota masyarakat mengembangkan bakatnya bermanfaat bagi perkembangan hukum dan tercapainya tertib hukum.

Bila diperhatikan dengan cermat, dari sekian banyak produk peraturan perundang-undangan tentang perlindungan terhadap perempuan, sudah selayaknya Negara Indonesia ini menempatkan perempuan pada prioritas utama untuk memperoleh perlindungan. Perlindungan itu baik dari segi juridis maupun non juridis. Namun harapan itu sampai sekarang masih sebatas "harapan dalam mimpi" dan persoalanpersoalan dan pelanggaran-pelanggaran terhadap hak-hak perempuan di Indonesia.

\section{DAFTAR PUSTAKA}

A. Gunawan Setiardja. 1993. Hak-hak Asasi Manusia Berdasarkan Ideologi Pancasila. Yogyakarta: Kanisius.

Bambang Sunggono 1994. Hukum dan Kebijaksanaan Publik. Jakarta: Sinar Grafika.

Bismar Siregar. 1983. Berbagai Segi Hukum dan Perkembangannya Dalam Masyarakat. Bandung: Alumni.

$\begin{array}{lcl}\text { Hukum } & \text { Dalam } & \text { Keadilan } \\ \text { Aspek } & \text { Hukumai } & \text { Nasional. } \\ \text { Jakarta: Rajawali. } & \end{array}$

Budiono Kusumohamidjojo. 1999. Ketertiban yang Adil Problematik Filsafat Hukum. Jakarta: Grasindo.

Darji Darmodihardjo dan Sidharta.1996. Penjabaran Nilai-nilai Pancasila Dalam Sistem Hukum Indonesia. Jakarta: Raja Grafindo Persada.

1999. Pokok-pokok Filsafat Hukum Apa dan Bagaimana Filsafat Hukum Indonesia. Jakarta: Gramedia Pustaka Indonesia.

Darwin Prinst. 1997. Hukum Anak Indonesia. Bandung: Citra Aditya Bakti. 
-1998. Hukum Acara

Pidana Dalam Praktik. Jakarta: Djambatan.

Maidin Gultom, 2014, Perlindungan Hukum Terhadap Anak dan Perempuan, Kumpulan Makalah-makalah Seminar, Refika Aditama, Bandung 